\title{
Hesitate Culture: Hampering Employees to Be a Whistle-Blower
}

\author{
Lilik Purwanti
}

\author{
Brawijaya University, Indonesia \\ Corresponding author. Email: lilik@ub.ac.id
}

\begin{abstract}
The purpose of this study is to determine the interest of employees to be whistle-blowers to prevent and detect fraud actions. This research uses a qualitative approach with a case study at Bank XYZ. Collecting data using interview method with selected informants. The study results indicate that employees are interested in being whistle-blowers because they feel the moral responsibility to disclose the activities of the crime, it has an obligation to report because they are protected by law, want to enforce regulations and secure state assets. On the other hand, some employees who are not interested in being a whistle-blower are reasoned that they feel compassion for the perpetrators because it can result in fraud being subject to legal sanctions and possibly being fired. In addition, employees feel that reporting the crime is an unethical action; the complainant is afraid of being threatened by fraud perpetrators and feels hesitate. The hesitate culture formed from the Javanese family environment can hinder employees from being whistle-blowers.
\end{abstract}

Keywords: Fraud, Hesitate, Qualitative Approach, Whistle-blower.

\section{INTRODUCTION}

The Financial Services Authority (OJK) functions as the sole authority of the Supervisor of the Financial Services Industry, particularly banking [1]. In the bank supervisory duties, the FSA found some indications of deviation from banking criminal acts' provisions that impact the bank's reputation. Every organizational activity must have uncertainty that is identical with risk, such as cheating risk (fraud) and not only results in reduced organizational assets but can also engage in reputation [2].

The Association of Certified Fraud Examiners (ACFE) defines fraud as a knowing misrepresentation of the truth or concealment of a material fact to induce another to act to his or her detriment [3]. States that there are 2,410 cases of occupational fraud investigated between January 2014 and October 2015 that occur in 114 countries globally with the highest fraud rate within one year of the banking industry and financial services [4]. OJK states that from 2014 to 2016 there are 108 cases of bank crime. In 2014 there were 59 cases, and then fell in 2015 to 23 cases and as many as 26 cases until the third quarter of 2016. The most prevalent cases in banking from 2014 to the third quarter of 2016 are the $55 \%$ credit case, $21 \%$ recording engineering, $15 \%$ embezzlement, $5 \%$ transfer of funds and $4 \%$ asset procurement. Nelson Tampubolon as Chief Executive Officer of the Banking Supervisory Board stated that banking operational activities have a high complexity of irregularities, both administratively and lead to criminal or fraudulent. Banking is an industrial sector that has a high potential for fraud compared to other industrial sectors, although banking is a sector that strongly adheres to government regulations. Regulation or regulation alone is not enough to combat fraud.

It is necessary to have internal control and supervision to prevent fraud. Having a good internal control system is one of the most effective tools in preventing and detecting fraud [5].In addition, early prevention of fraud is considered a solution to ward off potential actors, narrow the space, and identify activities at high risk of fraud. Applying the Whistleblowing System (WBS) is a form of internal control and prevention or disclosure of grievance in an organization [6]. Fraud can also be reduced or minimized by whistleblowing systems and knowing your employee. Effective whistleblowing systems 
will encourage the participation of employees in a company to be more willing to act to prevent fraud by reporting it to those who can handle it [7]. Whistleblowing system is a vital medium to control and detect fraud measures.

Whistleblowing is a disclosure by an employee or former employee of unlawful, immoral, or illegal practices to individuals or organizations that may have an effect of remedial action [ 8 ]. The whistleblowing actor is called a whistle-blower. Reports of the whistle-blower should meet specific criteria to be processed further. For example, the report should be supported by an obvious fact and true and reporting must be done only to prevent losses. It is in line with the statement of the NCG (National Committee on Governance Policies) that the complainant must provide clear evidence, information or indication of a reported violation so that it can be traced or followed up. Without adequate information the report will be difficult to follow up [9].

Benevolence factor, principle, organizational commitment, and seriousness of the offense positively affect employees' intentions to take internal whistleblowing measures, while egoism and personal cost negatively affect employees' intentions to engage in internal whistleblowing [10]. The seriousness of the violations may affect employee's intentions to carry out whistleblowing measures, while ethical factors, internal locus of control, organizational commitment and personal cost do not affect employee intentions to carry out whistleblowing actions. The study used a quantitative approach [11]. Civil servants agree that whistleblowing intentions can prevent fraud. Civil servants carry out their duties and obligations honestly, professionally and comply with the code of conduct and ethical standards in line with the vision and mission of the agency [12].

Delloite says that there are four reasons WBS fails to detect fraud, namely: the lack of Anonymity, organizational culture, policies and lack of awareness [13]. One of the whistle-blower barriers to reporting offenses is fear of being penalized. If employees have to report an offense and there is no guarantee of Anonymity, they may not provide information.

Organizational culture is formed based on the influence of top management. If management makes a bad example, employees will be silent for two reasons, first, they are afraid of being punished by management and second, they believe that management will not follow up on its report. If an acceptable behavior-related policy, employees are not sure about what the offense is and whether they should report suspicious activity or not. If WBS is not effectively well communicated, employees will not use it or do not know how to access it.

Based on the above description, this research is conducted to explore more deeply the interest of employees to perform whistleblowing system action as an effort to prevent and detect fraud action. This research was conducted at Bank XYZ's office in Jakarta. The research was carried out in the banking sector because the banking operations have a high complexity of deviation, both administrative or criminal acts or fraud. Differences with the previous research, not only the object of research, this type of research is qualitative with data collection techniques through in-depth interviews.

\section{RESEARCH METHOD}

\subsection{Types of Research}

This research is a type of qualitative research. The type of research is descriptive qualitative which produces descriptive data in words or oral words [14]. Qualitative research is a process of research and understanding based on a methodology that investigates social phenomena and problems of humans [15]. It is in accordance with the purpose of research which is to dig employee's interest in performing Whistle-blowing System actions. Qualitative research is a type of research whose findings are not obtained through statistical procedures or other forms of calculation and aim to express the symptoms in a holistic-contextual manner by collecting data from a natural setting by using the researcher's self as an instrument [16].

The instrument in qualitative research is the researcher himself (human research). In this case the research becomes the key instrument [17].

\subsection{Data Collection Methods and Informants}

Data collection is using in-depth interview method (in-depth) to the informants. Informants in this study are employees of Bank XYZ who are registered in Internal Management. The informant was selected by the researcher by reason of his willingness to provide information on the practice of whistleblowing system. Here is the list of names and positions of the informants. 
Table 1. List of Informants

\begin{tabular}{|l|l|l|}
\hline No. & Name* & Jobs \\
\hline 1. & Hani & Division of Internal Audit \\
\hline 2. & Eko & System Management Division \\
\hline 3. & Sigit & Division of Accounting and Tax \\
\hline 4. & Rina & HR Department \\
\hline
\end{tabular}

*The Informant's names are Pseudonym

\subsection{Data Analysis}

The interactive model data analysis technique consists of four steps [18]. Qualitative data analysis is an ongoing, iterative and continuous effort. The first stage is the data collection stage, the second stage is the data reduction stage, the third stage is the data display stage, and the fourth stage is the withdrawal phase conclusion and/or stage of verification [19]. The research results are presented in the form of narratives, tables or pictures. The last step is the conclusion of research and suggestions.

\section{RESULTS AND DISCUSSION}

\subsection{Understanding Employee Whistle- blowing System}

Employee interest in performing Whistleblowing systems strongly influenced his understanding, even though the employee who understands is not necessarily willing to do it. The interview result shows that all informants know and understand the application of the whistleblowing system in their office. Here's an informant statement about the whistleblowing system in his company.

"Whistleblowing is a system to accommodate employee reports about the fraud that occurred. It's secret and closed. Anyone has the right to use the system to report their bosses if they violate the rules. I think the WBS can prevent employees from cheating or violating ethics and rules." , said Hani. An employee in the audit division.

Another opinion was delivered by Eko (system management division). Eko sees the whistleblowing system used to report fraud issues and family problems. Here's the explanation:

"I am aware of the whistleblowing system here since the issuing rules regarding the implementation of this system. The whistleblowing system is a tool to report fraud-like problems and household problems. This is serious, you know, even this system is widely used to report such things", said Eko while laughing.
The same opinion was delivered by Sigit (Division of accounting and tax). Here's his opinion:

"Bank XYZ is very concerned about the lives of its employees. If anything is disturbing even in the household issues, it can be reported. The reports should be chosen selectively, not to report things that are not important. If a partner's actions may affect or interfere with employees, please you may report it, but if it is only an upset moment, don't report it haa haa", explains Sigit laughing loudly.

Rina (HR department) complements the opinions of previous informants. Here's the explanation:

"WBS means to report the occurrence of violations of codes of ethics and behavior, especially internal Bank XYZ and the public. This WBS is used to detect violations or fraud committed by an integrated employee from receiving the reports to follow-up. As a form of social control, the public can report suspected violations of ethics, conduct, and procedures performed by employees of Bank XYZ."

After drinking water, Rina continues her story about many reporting paths that can be used to report. Here's the story:

"How to report, you can send Short Message Service (SMS), e-mail, direct telephone, via website, facsimile, or send a letter directly to Bank XYZ. Clearer information about telephone numbers, $e$ mail and others can be found at our official website. Reports should be sufficient evidence and subsequently processed. Is it true that the complaint's report violates the behaviour or rules that applies?"

Based on the description of the informant above, whistleblowing system is understood as an effective tool to detect and prevent fraud. This opinion is in line with the expression of Bhal \& Dadnich that whistleblowing system is an important medium for controlling and detecting fraud actions [20].Based on the ACFE report, about half of the fraud cases were revealed because of reports from whistleblowers. Only a quarter of the fraud cases are revealed because of internal audits, and another quarter are revealed by other internal control processes or even by accident. 


\subsection{Reporting as Employee Liability Form to Enforce Per Rule and Secure State Property.}

Bank XYZ is bound by rules and procedures (company rules and procedures) and laws and codes (laws and professional codes). A regulation requires employees to go public if they see fraud or other types of violations. The code of ethics governs the behaviour of employees to act in accordance with applicable procedures. If employees do not act according to the procedure, then will be subject to sanctions. In addition, if the employee is aware of a violation but has not reported, then they will also be subject to punishment. Knowing but not reporting, the employee violates the rules that require employees to report. Here's Eko's opinion about employee interest in using whistleblowing system.

"Companies like banks have rules, procedures, laws and codes of conduct to be obeyed by all employees. If there are employees who violate it will be subject to sanctions. Moreover, employees who know someone has been cheating and not reporting, it will be penalized as well ".

At the middle of the interview, there is an employee asked for Eko signature. Eko asked permission to sign a file. Upon completion of the signature, Eko continued his story. Here's an advanced explanation of the benefits of WBS.

"Bank XYZ applies this system to keep employees' obedience to the rules, which will impact the security of State property. If employees work according to the prevailing rules, then there will be no cheating like corruption that harms the State. Therefore, WBS must be supported to prevent fraud or other unethical acts ".

A similar opinion was delivered by Hani (internal audit):

"As a financial institution, banks are prone to fraud. Anyone who knows someone else has cheated has an obligation to report, and the reporter is legally protected. This protection guarantee is expected to encourage employees' interest to report".

Sigit added the opinions of his two friends above, as follows:

"Work environment here is serious but relaxed and close like family, but we must still be professional. We have an employee code of ethics that requires us to be professional. If we see violations, should still we report because the rules bind us".
Based on the above opinion, the employee is interested in doing WBS as required by the regulation. Employees who see fraud or other types of violations should report. In the code of ethics, employees are required to have a professional attitude. If you see violations even with co-workers, they should be reported for harming the State.

\subsection{Moral Responsibility Reveals Crime for Creating Clean Environment.}

Bank XYZ is a Central Bank with supervisory and regulatory functions for banks. Must uphold ethics and create a clean performance in order to maintain the image in the eyes of the public so that it can be a good example for other banks. Bank XYZ has a moral responsibility (personal morality), employees must be in accordance with rules and codes of conduct and do not apply badly as a violation.

Sigit presented why WBS applied that Bank $\mathrm{XYZ}$ has a moral responsibility to the public. Bank as an institution must be trusted by the public who entrust their funds. Here's the detail explanation:

"We have a moral responsibility to the community so it must maintain a good image in public eye. This is very important considering we are the Central Bank. Logically, we issue rules to the banking, we want to obey the rules, but we ourselves be bad, how the story goes, not logical if our attitude so. So, we have to have good ethics to be an example of other banking".

Hani conveyed a similar opinion that Bank XYZ is maintaining the company's image. Fraud or unethical action is a very important issue to prevent and act upon. Next, we have Hani's explanation:

"The acts of fraud can damage the company's reputation and fraud is one of the actions that could damage the company's image. To prevent and overcome fraud, Bank XYZ implements a whistleblowing system, in which case it will create a clean environment free of fraud or other unethical actions".

Based on the above opinion it can be concluded that personal morality and social responsibility become motivation that can influence employees' actions to report fraud. This opinion is in accordance with the results of Lestari \& Yahya research [21]. This is done to create a good performance or clean environment and good corporate ethics, so that the company can be an example for other banks. 


\subsection{Hesitation and Tolerance Culture Become a Barrier to employees Interest in Being a Whistle-blower.}

As previously described, Bank XYZ has a corporate environment bound by company rules and procedures, laws and professional codes, social responsibility, and personal morality. In addition, Bank XYZ also has an environment based on kinship. This family-based work environment can be a factor that prevents employees from reporting.

Employees are not interested in to be a whistleblower because they feel compassion for the perpetrators, it can result in the perpetrators of fraud being subject to legal sanctions and possibly being fired.

Rina expressed no interest in doing WBS because he felt not hearted and pity if the offender is fired. The feeling in the language of Javanese is known as tolerance. Here's the explanation:

"A taste of family makes me feel not bear enough to report their own friends who commit fraud. She does not have the heart, pity if later punished and fired. What is the fate of his family?".

Hesitation culture has become one of the obstacles to implementing WBS. Rina is a Javanese who lives in a teacher's family and respects each other. Fellow employees, Rina feel uncomfortable or hesitate to report the fraud action. Even feel afraid of breaking friendship because the report is known by the perpetrator. After a long sigh, Rina continued the story:

"Many people who do not want to report, I think because they have a sense of shame. How could I report my own friend?. Moreover, cases on a small scale do not need to be reported. Never mind the small case, especially reporting their friend, so the senses of making complaints feel uneasy".

Based on the above opinion it is concluded that tolerance can hamper employees' interest to report. In addition, the culture is also uncomfortable impact the same. The hesitate culture formed from the Javanese family environment can hinder employees from being whistle-blowers.

\section{CONCLUSION}

This study explores employee's interest in being whistle-blower to prevent and detect the fraudulent act in Bank XYZ. This research uses qualitative approach with case study. Data collection is using in-depth interviews to informants. Informants in this research are employees of Bank XYZ. The results show that employees are interested in using WBS because whistle-blowers feel that they have a moral responsibility to maintain a good image and expose a crime, a reporting obligation protected by law, and want to enforce rules to secure State property. Conversely, some employees are not interested in doing WBS on the grounds of compassion because this action can cause the perpetrators of cheating to be fired, and fear of being threatened by the perpetrator. A kinship environment can form a culture that can hamper unwilling employees to report. In Javanese terms is called tolerance and hesitate.

\section{AUTHORS' CONTRIBUTIONS}

The results of the study provide evidence that employees have not fully implemented WBS or become a whistle-blower. Employees must support programs to eradicate fraud, corruption and other forms of fraud. The company or government is expected to be able to give rewards to employees who succeed in uncovering fraud uncovering fraud so that employees are willing to become whistleblowers.

Contribution for a family business is a profitmaking business so it must be ensured that there is no fraud in the company. A culture of honesty and responsibility must be upheld as leaders and employees, so that the family business in growing. A culture of hesitate and tolerance must be abandoned to uncover the occurrence of fraud. During the pandemic, almost all businesses experience a decline in sales and even profits, so it must continue to run a healthy business. Do not carry out activities that benefit yourself but detrimental to the company.

\section{ACKNOWLEDGMENTS}

By giving Alhamdulillah and thanks to Allah who has blessed the author in completing this paper. Thanks are conveyed to informants who have taken the time and are willing to be interviewed to obtain data in this study. Thank you to Brawijaya University for providing funds for this research. Next, say thank you for the family who sincerely give encouragement and prayers to the author so that this paper can be completed. 


\section{REFERENCES}

[1] OJK, Pahami dan Hindari: Memahami dan Menghindari Tindak Pidana Perbankan, Jakarta: OJK, 2017.

[2] Karyono, Forensic Fraud, Yogyakarta: ANDI, 2013, pp. 47.

[3] B.A. Garner, Black's Law Dictionary. 8th Ed., 2004. https://www.acfe.com/fraud-101.aspx

[4] Association of Certified Fraud Examinations (ACFE), Report to The Nation Occupational Fraud and Abuse. Austin, Texas: Association of Certified Fraud Examiners, 2016.

[5] W.S. Albrecht, C.O. Albrecht, C.C. Albrecht, M.F. Zimbelman, Fraud Examination, Fourth Edition, Mason: South-Western Cengage Learning, 2012, pp. 118.

[6] Bhal, K.T., Dadhich, A. J. Impact of Ethical Leadership and Leader-Member Exchange on Whistle Blowing: The Moderating Impact of the Moral Intensity of the Issue. Journal of Business Ethics, 2011, pp. 485-496, DOI: $10.1007 / \mathrm{s} 10551-011-0876-\mathrm{Z}$

[7] Suharto, The Effect Of Organizational Culture, Leadership Style, Whistleblowing Systems, And Know Your Employee On Fraud Prevention In Sharia Banking, Asia Pacific Fraud Journal, Vol. 5 (1), 2020, pp. 108-117, DOI: 10.21532/apfjournal.v5i1.141.

[ 8 ] M.P. Miceli, J.P. Near, Organizational Dissidence: The Case of Whistle-Blowing, Journal of Business Ethics, 1985, pp. 1-16, DOI: $10.1007 / \mathrm{BF} 00382668$

[9] T.M. Tuanakotta, Akuntansi Forensik \& Audit Investigatif, Jakarta: Salemba Empat, 2012, pp. 611.

[10] I. Setyawati, K. Ardiyani, C.R. Sutrisno, Faktor-faktor yang Mempengaruhi Niat untuk Melakukan Whistle-blowing Internal, Jurnal Ekonomi dan Bisnis, Vol. 17 (2), 2015, pp. 22 33,

DOI: http://dx.doi.org/10.31941/jebi.v17i2.334

[11] R. Lestari, R. Yaya, Whistleblowing dan Faktor-faktor yang Memengaruhi Niat Melaksanakannya oleh Aparatur Sipil Negara, Jurnal Akuntansi, Vol. 21 (3), 2017, pp. 336350 .

[12] L. Tripermata, Syamsurijal, T. Wahyudi, L. Fuadah, The Driver of Whistleblowing
Intention and Fraud Prevention: Attitude and The Ethical Culture of The Organization, Sriwijaya International Journal of Dynamic Economics and Business, Vol. 5 (1), pp. 91110, 2021, DOI: https://doi.org/10.29259/sijdeb.v5i1.91-110.

[13] W.S. Albrecht, C.O. Albrecht, C.C. Albrecht, M.F. Zimbelman, Fraud Examination, Fourth Edition, Mason: South-Western Cengage Learning, 2012.

[14] L. Purwanti, D.S.A. Fatmawati, The Meaning Of Regional Assets Inventorying: Perspective Of Asset Administrators, 23rd Asian Forum of Business Education (AFBE 2019), Advances in Economics, Business and Management Research, Atlantis Press SARL. 2020, pp. 165168

[15] J.W. Creswell, Research Design: Qualitative, Quantitative and Mixed Methods Approaches (4th ed.), Thousand Oaks, CA: Sage, 2014, pp. 15 .

[16] L. J. Moleong. Metode Penelitian Kualitatif, Edisi Revisi, Bandung: PT. Remaja Rosdakarya, 2018, pp. 6.

[17] L. Purwanti, I. Triyuwono, G. Irianto, A. Riduwan, Cosmetics and Tricks: Representing the Meanings of Earning Management Practices, Procedia - Social and Behavioral Sciences 211, Elsevier, 2015, pp. 704-710, DOI: 10.1016/j.sbspro.2015.11.106

[18] B.M. Miles, A.M. Huberman, J. Saldana, Qualitative Data Analysis, A Methods Sourcebook (Edisi 3), New York: SAGE Publications, 2014, pp. 69.

[ 19 ] H. Herdiyansah, Metodologi Penelitian Kualitatif untuk Ilmu Psikologi, Jakarta: Salemba Humanika, 2015

[20] K.T. Bhal, A. J Dadhich, Impact of Ethical Leadership and Leader-Member Exchange on Whistle Blowing: The Moderating Impact of the Moral Intensity of the Issue, Journal of Business Ethics, Vol. 103 (3), 485-496, 2011, DOI: $10.1007 / \mathrm{s} 10551-011-0876-\mathrm{Z}$

[21] R. Lestari, R. Yaya, Whistleblowing dan Faktor-faktor yang Memengaruhi Niat Melaksanakannya oleh Aparatur Sipil Negara, Jurnal Akuntansi, Vol. 21 (3), 2017, pp. 336350. 